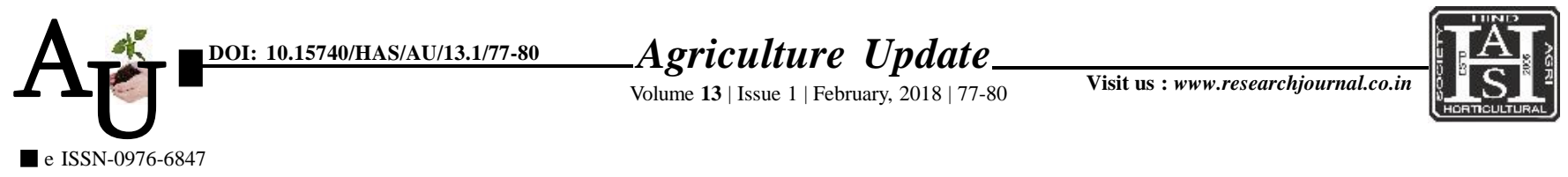

\title{
Rевевси автісів: Yield gap analysis for chickpea (Cicer arietinum Linn) through front line demonstration in Indore district
}

A.K. Shukla, Nitin Pachlaniya, D.K. Mishra and Alok Deshwal

Article Chronicle :

Received :

01.12.2017;

Revised :

29.12.2017;

Accepted :

15.01.2018

KeY WoRdS :

Chickpea, Yield gap,

FLDs
SUMMARY : Enhancing the production potential and socio-economic level of farmers, 138 front line demonstrations on chickpea were laid out during the year 2015-16 and 2016-17. Area under the demonstration was 50.56 hectare comprising 138 farmer's of six villages Ramukhedi, Setkhedi, Khudel, Baroda Doulat, Gariya and Akya of district Indore in Madhya Pradesh. Under the technology dissemination programme recommended intervention i.e. suitable variety, integrated nutrient management, integrated pest management were attempted. Recommended practice recorded mean yield of $14.40 \mathrm{q} / \mathrm{ha}$, which was 30.11 per cent higher over the farmers practices $(11.06 \mathrm{q} / \mathrm{ha})$. Additional cost under the intervention of Rs. 2740 to 1919 gave additional net return of Rs. 10,917 to Rs. 15,046 per hectare. Higher side benefit: cost ratio (2.4-2.51) was recorded during both the year of study. The extension gap was observed between 3.01 to $3.6 \mathrm{q} / \mathrm{ha}$. The favourable cost benefit ratio exhibited the feasibility of technology demonstrated.

How to cite this article : Shukla, A.K., Pachlaniya, Nitin, Mishra, D.K. and Deshwal, Alok (2018). Yield gap analysis for chickpea (Cicer arietinum Linn) through front line demonstration in Indore district. Agric. Update, 13(1): 77-80; DOI : 10.15740/HAS/AU/13.1/77-80.
Author for correspondence :

\section{A.K. Shukla}

Krishi Vigyan Kendra,

Kasturbagram, Indore

(M.P.) India

Email:arunpagarbhu@

gmail.com

See end of the article for authors' affiliations 